\title{
Multi Perspectives on Play Based Curriculum Quality Standards in the Center Learning Model
}

\author{
Hapidin $^{1}$ \\ Universitas Negeri Jakarta, Indonesia ${ }^{1,2,3}$ \\ R. Sri Martini ${ }^{2}$ \\ Eriva Syamsyiatin ${ }^{3}$
}

DOI: https://doi.org/10.21009/JPUD.141.02

Accepted: February $15^{\text {th }} 2020$.Approved: March $4^{\text {th }} 2020$. Published: $30^{\text {th }}$ April 2020

\begin{abstract}
Playing curriculum development based on early childhood learning is a major issue in international early childhood education discussions. This study aims to look at the concepts and practices of play-based curriculum in early childhood education institutions. The study uses qualitative methods with the CIPP model program evaluation on play-based curriculum. Data collection techniques were carried out using participatory observation, document studies and interviews. Participants are early childhood educators, early childhood and parents. The results found that the play-based curriculum has not yet become the main note in the preparation and development of concepts and learning practices in early childhood. Play-based curriculum quality standards have not provided a solid and clear concept foundation in placing play in the center of learning models. Other findings the institution has not been able to use the DAP (Developmentally Appropriate Practice) approach fully, and has not been able to carry out the philosophy and ways for developing a curriculum based on play. However, quite a lot of research found good practices implemented in learning centers in early childhood education institutions, such as develop children's independence programs through habituation to toilet training and fantasy play.
\end{abstract}

Keywords: Play Based Curriculum, Center Learning Model, Curriculum Quality Standards, Early Childhood Education

\footnotetext{
${ }^{1}$ Corresponding Author:

Email: hapidin@unj.ac.id

Universitas Negeri Jakarta, Indonesia
} 


\section{INTRODUCTION}

Today special attention to improving access to early childhood care and education programs and producing high-quality educational experiences for children continues to grow throughout the world. Cortázar's (2015) study assessed the impact of early childhood education programs in Chile with the national Education Quality Measurement System (SIMCE). The findings show that not all children get the same benefits from attending Early Childhood Care and Education (ECCE). Many factors affect the success of improving early childhood education.

One reason is the knowledge of early childhood educators on what children need for future academic success in a play-based and child-centered program and not present in an early childhood program led by teachers and worksheets. One of the most extensive studies takes place in Washington, DC, D.C. over the past 5 years finding children in academic-oriented classes decreased in skills over the next few years to end up substantially behind their peers, and Kathy (2016) found a cause for this, namely child-centered (play based); teacher centered (direct academic instruction such as memorization and worksheets); and combination. Children learn in kindergartens, but decline by $22 \%$ in the relative skill level in elementary grades.

A consensus has now been established on quality of early childhood care and education (ECCE) services provided to all children, especially those in marginalized communities caused by social or economic disparities. However, the debate has shifted from access to quality. While all parties agree that quality ECCE services for children, debate about what makes up quality is ongoing. Quality in education is notoriously difficult to define, the reason being, among others, in many cases it is rarely monitored (Ejuu, Apolot, \& Serpell, 2019).

Early childhood quality's education towards the concept of activity-based learning in early childhood, that the play basically refers to the way an activity out, an approach that advocates a play-based curriculum, means that learning in meaningful practices (practices that make sense culturally and personal) that follows the game format. The important and different characteristics of this approach emphasized briefly here. In this view, play-based curriculum is not just a curriculum that allows children to play for a while (apart from studying and working). In the playbased curriculum, Develop children quality's education is an important characteristic of all children's activities, and opportunities to teach embedded in these activities at times that make sense to students (van Oers, 2012).

Attention to the psychological and sociological values of per-toy based learning in early childhood is still minimal. Researchers from the fields of education and psychology have suggested 'playing' is a powerful mediator for learning various skills throughout one's life (Ali, Kaitlyn M, Hussain, \& Akhtar, 2018). Mcginn (2017) examining the effects of game-based early childhood curricula on develop social and academic contracts for pre-schoolers found a positive correlation between free play in early childhood and future school success in terms of literacy and social development and recommendations for improving teacher practice and education policy.

Basically, curriculum development seen as a multi-faceted development trajectory based on play activities in early childhood education (van Oers, 2015). Such a curriculum offers (relative) freedom to educators and opens up introducing meaningful culture into children's activities and a curriculum that helps teachers to encourage meaningful learning for children is a play-based curriculum. Van Oers dan Duijkers (2013) explain the theoretical basis of the approach and how it is elaborated in a play-based curriculum for early classroom classrooms (ages 4-8 years). The findings show that teaching in a play-based curriculum not only makes theoretical and practical 
sense, but also seems effectively useful for achieving positive outcomes compared to approaches that are solely driven by teachers.

Peng (2017) testing the understanding of twenty teachers about play-based curriculum and the relationship of play literacy. The findings suggest that Chinese kindergarten teachers need to balance various educational approaches, mediating benefits and conflicts based on the benefits of children's development through the professional development of kindergarten teachers. A similar thing happened in post-colonial developing countries such as Indonesia, it requires a complete understanding of understanding in early childhood teachers to master bring about educational aspects through an appropriate curriculum for early childhood.

Research has shown the development and educational benefits of the game. Apart from these benefits, academic instruction directed by teachers is very prominent in kindergartens. There is recognition in the curriculum and policy of the challenges posed by the lack of classroom play and the need to support academic learning using practices that are suitable for development. Pyle dan Danniels (2017) High resolution that focuses on playing as a practice for children, which teacher about this pedagogically agreed application. Research results on practice or policy on play-based learning consumption offer broader and more concrete play-based learning resolution to help teachers who approve this pedagogy and to improve play-based learning studies in year-long research early.

The latest debate on pedagogy in the early years addresses the challenges faced by teachers when they choose between teaching academic content through direct instruction or giving children time to engage in child-led play (Chien et al., 2010). Special emphasis in early childhood education about the play important. Faas, Wu, \& Geiger (2017) look at various perspectives on learning to play. The focus is on strengthening practices that are suitable for development, childcentered learning and play-based learning, and early literacy, arithmetic, and natural science, all of which emerge as elements of international trends or international reform movements.

Based on various learning curriculum problems applied and various studies on play-based curriculum in early childhood education should play activities as a core part of the curriculum for early childhood education become the focus of research observations at the Ceria Educational Development Center for Children. Early Childhood Education Laboratory, Faculty of Education, Universitas Negeri Jakarta. As an academic laboratory, the TTKA Ceria service program should conduct learning by referring to the study of academic concepts and various good practices in the PAUD field. Therefore, it is necessary to check the laboratory program policies. The purpose of this study is through program evaluation to find the feasibility, usefulness and implementation of play-based curriculum that is a reference in organizing the TTKA Ceria Faculty of Education at Universitas Negeri Jakarta program.

\section{THEORITICAL STUDY}

\subsection{Play-based Learning}

Many researchers debate how to define the concept of children's play, and there is still a disagreement about what human actions are included in this activity, why children are involved in it, and how it impacts learning and development (Wallerstedt \& Pramling, 2012). Children's games as something that freely chosen, actively involved, opportunistic, fun, creative, and more concerned with means than goals (Ashiabi, 2007; Sturgess, 2003). Although many of these ideas 
lay the foundation for the conceptualization of different games, two types of games have dominated the focus of current research in education, children's play games and games guided by adults (Weisberg, Zosh, Hirsh-Pasek, \& Golinkoff, 2013).

The term free play is often used to describe games with children as direct, voluntary, and flexible, such as involving pretend play (Fisher, Hirsh-Pasek, Newcombe, \& Golinkoff, 2013; Holt, Lee, Millar, \& Spence, 2015; Weisberg et al., 2013). Play is an activity that children as leaders separate from learning, whereas learning is the result of activities with the teacher as a leader and has a higher priority in classroom settings (Samuelsson \& Johansson, 2006). Although conceptualizing games and learning in a dichotomous way is common, many researchers and professionals emphasize the idea that development and learning need play as a tool. Wallerstedt dan Pramling (2012) Will and Jon argue that in a child's early life and learning does not stop once the lesson is finished, because learning cannot separate play and learning.

Play-based learning as a teaching approach that involves elements that are fun and child-led with adult guidance and learning goals prepared in advance (Weisberg et al., 2013). In addition to the academic benefits of games, researchers have found a connection between games and social-emotional skills. For example, mock games have been found to support self-regulation skills (Berk \& Meyers, 2013). Alternative perspectives describe play as an opportunity for children to internalize and explore academic concepts, where teacher involvement as an opportunity to improve children's learning achievement (Pyle \& Bigelow, 2015).

This type of play-based learning is effective because it actively involves children in activities (van Oers \& Duijkers, 2013; Weisberg et al., 2013) and the level of involvement in maintaining and implementing several elements with the teacher as the leader. In addition, there is evidence that emphasizes game-based learning as collaboration between students and teachers leading to positive academic outcomes (van Oers \& Duijkers, 2013). therefore, researchers have begun to highlight the need to learn different types of games and the potential benefits of play-based learning for children's development and acquisition of important skills (Bodrova, Germeroth, \& Leong, 2013).

Play is an important element in early childhood education programs, because it provides opportunities for young children to (1) express their ideas and feelings, (2) symbolize and test their knowledge of the world, and (3) get effective support for academic learning and nonacademic. Through games, early childhood in active learning as they build their experiences, generate ideas, and test ideas. Teachers need to develop play activities that relate to the educational goals of the program. Play also allows children to integrate ideas and experiences so they build knowledge and make most of their goals (Saracho, 2010).

Books, research and theory prove the use of children's games as a curricular tool in children's education. Then suggest practical applications related to children's play for each area of aspects of child development and learning subjects. In the curriculum of the game, must handle various forms of knowledge and foster various forms of intelligence. As well as Requiring Ideas how teachers can choose the resources available to them, the resources of time, space, physical material, and human resources in building high-quality educational programs for children (Saracho, 2013).

Play-based learning is a type of early childhood education that is based on games led by children and open play. Playing itself is a fun voluntary activity without a goal or end goal. Activities 
like these lay the foundation for a child to become a curious and passionate learner later on. Playbased learning helps children develop social skills, learning motivation, and even language and numeracy skills. Taking the initiative, focusing, and curiosity about the world are part of the game. Children are naturally prepared to do things that will help them learn and grow.

\subsection{Play-Based Curriculum}

\subsubsection{Conceptualize Play-Based Curriculum}

Planning curriculum development for early childhood, teachers must imagine and think about important theoretical concepts and the relationship between play and pedagogy. A model provides an opportunity for children to conceptualize the child's role as a learning leader, interpret games and pedagogy in original ways while discussing the teacher's role in framing, supporting, and balancing teacher interactions with children to plan to support shared thinking. Educator's Guide to Early Years Learning Framework (EYLF): Belonging, Being, and Becoming, gives educators the role of pedagogy in play-based curriculum documents. The framework says play provides opportunities for children to learn, when children find, create, improvise and imagine. The immersion or sinking of children in their play illustrates how the game allows children to simply enjoy being. However, ways educators immerse themselves in children's play and encourage children in 'being' remain open to further research (Ridgway \& Quinones, 2012).

The concept in the play-based curriculum can involve 42 other concepts, Ridgway dan Quinones (2012) such as, everyday concepts, scientific concepts, experiences, spaces, materials, theoretical knowledge, interactions, environment, teachers, family culture, playing from the perspective of children, playing from the perspective of adults, learning, government framing, social dimensions culture, community, peers, thinking together on an ongoing basis, knowledge funds, rules of play, effective pedagogy, self-motivation, pre-school, initiated adults, initiated children, imagination, motives, culture, daily practice, inquiry, institutional practices, model movements, economics, creativity, symbolic meaning, rules, time and space, integrated learning, development, investment, freedom, and attraction.

The aim of the game-based curriculum is to transfer this important attitude to quality learning. However, the reality is that pseudo play with teacher's direction cannot make that goal. Wong, Wang, dan Cheng (2011) examined Hong Kong kindergarten children spending most of their school days after the teacher's instructions; there is little room for the free playful expression of children themselves. Game-based curriculum functions in a way that teachers need to listen to what children are saying and review curriculum and pedagogy. Games that are authentically initiated by children and motivated by themselves, children actively involved and benefit from them. Teachers need to follow the children's instructions and become observers sharp enough to find moments that taught and not impose a learning agenda on children. The results of this study also suggest continuing research to investigate how children's demographic backgrounds and school experiences influence their games.

\subsubsection{Supporting Factors for Play Based Curriculum}

Educators who apply play-based learning curricula now face the challenge of integrating academic standards in game-based pedagogy. While some researchers and educators have supported the viewpoint that play should stay an effort with children as directors, educators have reported concerns about meeting academic standards without being able to offer some direction 
during play time. An integrated approach to play-based learning that addresses developmental and academic benefits is widely recommended (Danniels \& Pyle, 2018). To integrate developmental and academic approaches, play-based learning conceptualized as a continuum that combines various levels of adult involvement in games.

Activities with children as leaders (free games) at one end of the continuum while games with teachers as leaders (learning through games) fall at the other end, with games that lead each other (collaboratively designed games) in the middle place. When implementing a game-based learning continuum, educators negotiate a balance between allocating time for free games without distractions and embedding or expanding academic content in different ways in fun activities to support children's learning. By providing various types of games in the classroom where educators take on various roles, to overcome the learning of developmental and academic skills in ways that are child-centered, interesting, and under development. This broader definition of play-based learning might help bridge the gap between developmental and academic perspectives in the game, and improve practice (Danniels \& Pyle, 2018).

Some of the most helpful aspects in the school environment include having supportive leaders who are very understanding and passionate about classroom-based learning. Another aspect which is the play-based curriculum which is a challenge for educational institutions to organize a play-based curriculum include:

\subsubsection{Resources}

The challenge of using resources and availability when implementing play-based curriculum pedagogy. The teachers indicated more resources to run a regular play-based program with small groups participating in the center of learning or learning with the center model. The lack of other adult resources to help small group work impacts on the offer of this type of activity. Martlew, Stephen, dan Ellis (2011) in their research concluded that even when teachers want to apply new practices such as active learning to play in class, they need other resources and training.

\subsubsection{Time}

Play-based activities need more time in practice compared to structured teaching strategies. teachers need extra time to teach and then arrange children to learn exploration and extra time to follow the discovery of new things in studies of curriculum-based play. A dense curriculum design requires the teacher's expertise in finding time to adjust everything. When doing play based properly, children calmly play and learn, even though they spend most of the time but are effective for aspects of child development. Likewise changing teaching practices and pedagogy requires time and so to sustain them requires the much effort (Jay \& Knaus, 2018).

\subsubsection{Environment, Curriculum and Assessment}

The environment for play-based curriculum is the main support for playing activities. These factors include the space in the classroom and the model of the surrounding centers, sharing available space with other classrooms and handling noise. The impact of organizational factors and 'space poverty' on the classroom environment is a problem and impedes opportunities to play a role (Rogers \& Evans, 2007).

Other problems include a dense curriculum and the need to check according to National standards including requirements for moderation at all grade levels. Teachers find it difficult to adjust 
everything they expect taught and this hinders their ability to start a play-based program. Standard principles of assessment urge teachers to make informed and balanced assessments that involve evaluating school performance and systems based on a variety of reliable sources of evidence that relate to not only academic goals but also include the main social-emotional goals of the school (Klenowski \& Wyatt-Smith, 2012).

Assessing children's learning in game-based activities is quite difficult and good documentation and teacher observations are very important. assessments taken in play-based learning are rigorous and that with so many children, limited time, and limited adult help to assess all children during play becomes quite difficult.

\subsubsection{Behaviour}

In children's reaction to game-based programs, many teachers think that children seem to enjoy the experience and involve it in all activities. Some concerns about classroom behavior arise including children becoming overly excited when the teacher introduces new activities. Hope Children will behave well and continue to work on the task by developing collaborative skills. Sometimes some teachers are afraid of the possibility of "losing class control", while other teachers can turn it into a positive aspect of play-based learning by applying the learning center as a strategy to improve behaviour (Jay \& Knaus, 2018).

\subsubsection{Experience}

The lack of teacher experience with play-based learning and the need to change their mindset has an impact on their experience. Teachers' attitudes to the value of games as authentic learning strategies, regardless of their teaching qualifications, develop when they engage with young children and teachers can improve their personal teaching approaches.

\subsection{Benchmark Play-based Curriculum}

Another challenge for implementing play-based learning is putting pressure on teachers from schools and system administration about standardized testing (Miller \& Almon, 2009). One result of the National Assessment Program - Literacy and Numeration (NAPLAN), such as testing is to put pressure on teachers to meet targets and the effects of teaching ripples for examinations (Klenowski \& Wyatt-Smith, 2012). The government needs to carry out an agenda like this to improve education quality and enable transparency and accountability(Thompson, 2013). Testing often results in narrowing of the curriculum which has a negative impact on the teaching and learning of certain content (Reid, 2009). The drive to improve test results has an impact on the school, even in kindergarten and pre-primary schools (Thompson, 2013). Alford, Rollins, Padrón, \& Waxman (2016) point out that formal instruction has now become standard in the first year of elementary school. Observing early childhood completing the activities of the class while sitting at the table and the teacher commenting openly about preparing students

for the exam. Taking into account the overall development of children, especially when applying to children in the early years, social-emotional development and attitudes towards learning in school. Research therefore recommends opportunities to learn through a more active play-based approach.

Benchmarking is a benchmark or benchmark for evaluating or measuring something (eg curriculum). Benchmarks for early childhood education curriculum refer to references from experts who concentrate of studies on the curriculum. Early childhood education experts have 
various perspective perspectives related to the concept of play-based curriculum (Hennessey, 2016). Montessori is one of the figures who often becomes a reference (benchmark) in understanding the concept of playing-based curriculum. Some standard reference components in the Montessori curriculum include (1) philosophy about children, (2) learning objectives and principles, (3) learning content, (4) the role of the environment, (5) playing material, and (6) the role of the teacher (Özerem \& Kavaz, 2013).

Preparation of curriculum standard references at PAUD Institutions in Indonesia refers to the national standards for early childhood education (SN-PAUD) by Minister of Education and Culture Regulation number 137 of 2014 and number 146 of 2014 about 2013 PAUD curriculum. Some reference standards (benchmarks) carry out play-based curriculum (article 9 of Ministry of Education and Culture 137 of 2014) has several components. The intended components include (1) institutional self-evaluation documents, (2) documents 1 KTSP, (3) documents 2 containing learning tools and (4) implementation procedures documents according to standards. Institutional self-evaluation is a process of analysis of the various components of the Institution which is a reference to close the Institute and the profile of the Institution. The self-evaluation process is usually carried out using context analysis using the SWOT analysis or SWOT analysis (SStrength, W-Weakness, O-Opportunity and T-Threat). This approach analysis the Institute from aspects of the strengths and weaknesses of the Institution as well as the opportunities and threats of the Institution (Pendidikan \& Kebudayaan, 2015).

The second part is curriculum level unit educator documents (document $1 \mathrm{KTSP}$ ). This document becomes a master document and a reference for educators in developing and developing learning tools and SOPs needed. The third part is a learning tool a micro curriculum document at the level of educators conducting operational learning in the classroom. These components usually include semester themes and programs, preparation of weekly learning plan implementation documents and daily learning implementation plans. In the fourth part is the implementation procedure document under the standard (Pendidikan \& Kebudayaan, 2015).

\section{METHODS}

The method used in this study is a qualitative approach to the evaluation program design with the CIPP model developed by Stufflebeam (2003). This model starts from the view that various factors influence the success of an educational program, such as the characteristics of students and the environment, the purpose of the program and the use of equipment, ways and the implementation mechanism of the program itself. This evaluation program intends to compare various program dimensions with a number of specific criteria, to finally arrive at a description and judgment about the strengths and check the weaknesses of the program.

\subsection{Participant}

Participants are early childhood educators, early childhood and parents in TTKA Ceria class of 2018-2019. The research place is based on TTKA Ceria Institute as a program unit of the Faculty of Education at Universitas Negeri Jakarta program laboratory that serves the needs of parents in providing care, care and education for early childhood. Program evaluation on TTKA Ceria services focuses on the Implementation of Play Based Curriculum. Conducting research from April to October 2019. 


\subsection{Data Collection}

This research data focuses on a some key aspects which are the basis for a play-based curriculum. The basic data types are (1) document data on the basis of curriculum development, (2) document data 1 curriculum at the PAUD Education unit level, (3) learning device data, (4) playing process implementation data, (5) spatial governance data in and outside, (6) data on the results of child development assessments and (7) annual Institute program data. Data collection using the method of observation, interviews, document analysis and questionnaires. Data sources are TTKA Ceria's head, Early Childhood Education study program coordinator, Educator, parents and students. Focus data collection techniques to see events in the field, with the aim of describing matters relating to nature-based learning center activities.

\subsection{Procedure}

Data collection procedures are as follows; (1) Submission of research objectives in the cheerful TTKA Institute, (2) Presentation, discussion and brainstorming about curriculum-based play, (3) Observation of learning activities, (4) Interviews with various sources, (5) Analysis of curriculum documents and learning tools, (6) Compilation of data coding and classification.

\subsection{Instrument}

Data analysis uses standard references (benchmarks) in evaluating variables. Evaluate variables according to the theoretical references as follows:

Table 1. Play-Based Curriculum Evaluation Instruments

\begin{tabular}{ll}
\hline Variable & Benchmarking \\
\hline $\begin{array}{l}\text { Institutional self- } \\
\text { evaluation }\end{array}$ & $\begin{array}{l}\text { ECE has a self-evaluation result which includes eight components. } \\
\text { The results of the self-evaluation were compiled jointly by a team that } \\
\text { involved the educator } \\
\text { There is a process of analysing data on self-evaluation documents } \\
\text { There are results of the Institutional self-evaluation in the form of } \\
\text { institution status }\end{array}$ \\
\hline $\begin{array}{l}\text { The foundation of } \\
\text { curriculum development }\end{array}$ & $\begin{array}{l}\text { ECE institutions have academic manuscript documents that serve as a } \\
\text { reference and foundation in developing the curriculum } \\
\text { The foundation of curriculum development is in accordance with the } \\
\text { needs, characteristics, vision and mission of the Institute. }\end{array}$ \\
\hline $\begin{array}{l}\text { ECE Education unit level } \\
\text { curriculum }\end{array}$ & $\begin{array}{l}\text { ECE institutions have Education unit-level curriculums that are self- } \\
\text { developed and developed. } \\
\text { Standard Competencies Program ECE has complete document contents, } \\
\text { understood and used as a reference in carrying out learning activities. }\end{array}$ \\
\hline Learning Tools & $\begin{array}{l}\text { ECE institutions have a complete set of learning tools that serve as a } \\
\text { reference for education to provide services to early childhood }\end{array}$ \\
\hline $\begin{array}{l}\text { The process of } \\
\text { implementing play } \\
\text { activities }\end{array}$ & $\begin{array}{l}\text { Institutions show the learning process through the variety of play, play } \\
\text { tools and duration of play. }\end{array}$ \\
\hline $\begin{array}{l}\text { Space management } \\
\text { inside and outside }\end{array}$ & $\begin{array}{l}\text { ECE institutions have spatial management inside and outside that meet the } \\
\text { standards of infrastructure in accordance with the needs, characteristics } \\
\text { and stages of child development. }\end{array}$ \\
\hline
\end{tabular}




\begin{tabular}{ll}
\hline $\begin{array}{l}\text { Results of assessment of } \\
\text { child development }\end{array}$ & $\begin{array}{l}\text { ECE has a plan for conducting child development assessments and is } \\
\text { reported according to the consensus of the time the results of the } \\
\text { assessment are given }\end{array}$ \\
\hline $\begin{array}{l}\text { Institutional annual } \\
\text { program }\end{array}$ & $\begin{array}{l}\text { ECE has an annual program of Institutions that is carried out consistently } \\
\text { and regularly }\end{array}$ \\
\hline $\begin{array}{l}\text { Standardized operational } \\
\text { procedures }\end{array}$ & $\begin{array}{l}\text { ECE institutions have various SOP on various aspects of service that are } \\
\text { technical in nature }\end{array}$ \\
\hline
\end{tabular}

\section{RESULT AND DISCUSSION (HASIL DAN PEMBAHASAN)}

\subsection{Result}

\subsubsection{The Concept of Implementing a Play-Based Curriculum}

The Joyful Child Growth Garden (TTKA Ceria) is one of the laboratories education units for early childhood education of the Early Childhood Teacher Education Program, Faculty of Education, Jakarta State University. This institution was established in 2001 with the first goal of providing PAUD services for early childhood groups from marginalized families around the Universitas Negeri Jakarta. As an educational laboratory unit, TTKA Ceria has become an official laboratory that has had educational infrastructure and education staff since 2006. This laboratory unit has provided ECE services in the form of a Childcare Park program which often also gets the name day-care and ECE educators as educates.

The TTKA Ceria laboratory unit has placed the concept of emergent curriculum (emergent curriculum) and the concept of learning practices that are to the stage of child development (DAP). Emergent curriculum is a perspective and philosophy that places the learning process and curriculum planning which is focused on responsive attitudes to the interests and needs of children to gain meaningful learning experiences (play) in various classroom situations. Emergent curriculum philosophy has four main components as supporting pillars, namely (1) Environment, (2) Role of Educators, 3) Observation and Documentation and (4) project work and project practices.

The Development Appropriate Practice (DAP) concept is used as a platform to look at the interests, needs and stages of the child's real development which are the basis for developing programs and using proper learning practices. The use of the DAP concept is carried out through, among other things, developmental assessment activities and children's learning needs. The results of the assessment data form the basis for developing programs and learning activities for each child or several groups of children through learning centers.

\subsubsection{Implementation of Play Based Curriculum}

As a necessity, Faculty of Education at Universitas Negeri Jakarta program tries to design and develop an educational laboratory that used as a place to conduct various academic practices of lecturers and students, especially in testing and developing scientific knowledge and educational practices in early childhood. One of the academic and practical tasks, from TTKA Ceria is to compile, develop and make the concept of play-based curriculum as the main pillar of ECE experts in implementing the curriculum. 
Play-based curriculum is carried out at the TTKA Ceria Institute through various forms of play-based learning planning and practice. In the planning stage, the choice and development of themes become the main activities carried out by ECE educators through discussion forums and workshops led by the coordinator in charge (coming from lecturers appointed by the head of the study program) and technical coordinators who direct and arrange technically with educators. In addition to themes, planning activities continued with a learning syllabus for each learning period on a theme. The ready syllabus has learning activities (play), learning content, competencies and indicators of development as well as the media and learning resources used. Based on this syllabus, educators compile and develop a daily activity plan that is prepared on an ongoing basis.

In the planning section, structuring the playing environment and playing tools is also a mainstay of implementing a play-based curriculum. Every educator and usually assisted by ECE Educator Program students try to work together to present a learning environment with themes being discussed. Attempts to present thematic nuances usually occur and are carried out since the entrance or entrance of the child. In the process, educators also usually try to display performances that are the themes discussed. In addition, in structuring the playing environment, educators also prepare play materials and play assignments to be carried out by children at each center. With a large increase in academic expectations and standards, educators face the challenge of integrating it into a learning experience that is developmentally appropriate for children in kindergartens. To meet this challenge, the role of playing in the classroom with an emphasis on practices that are appropriate to developments such as play-based learning (PBL). PBL is child-centered and focuses on children's academic, social and emotional development, as well as their interests and abilities through learning experiences that are mentally appropriate and develop. Like the results of Taylor \& Boyer's (2020) research that explores the definition of play-based learning (PBL), the theoretical framework and historical research that has shaped PBL, the various types of games, PBL's social and academic benefits, and the ways in which educators can facilitate, support, assess, and use technology to improve PBL. The findings conclude by reflecting on how teaching practices can be informed by evidence-based research to improve children's learning experiences in kindergarten classrooms

\subsection{Best-Practice Findings}

\subsubsection{Modelling}

Modelling is one of the findings of good practice implement play-based curriculum in TTKA Ceria ECE Lab school, Faculty of Education, Jakarta State University. Modelling puts the teacher as an example of a model in various forms of speech, attitudes and behaviours that children refer to. To make this good practice, educators must first have an attitude of patience, remind children and tell children, and set good examples for children. The teacher gives a good and clear example so that the child can better understand what the educator means. If a child makes a mistake the educator tells the child that it is not good. The process is also through various forms of daily habituation in children.

\subsubsection{Fantastic Play}

When introducing firefighters, children are invited to know the story of George. The story of George with the yellow hat man. Based on George's story book, the teacher makes the story come true. The teacher makes it as if the child enters into the world of George, then he meets a man in 
a yellow hat. The children are attempt, the contents are children making extinguishers. Hats to play fantasy again. Fantasy play in the form of continuous play activities (continuum play) between fantasy play activities on the first, second, third day and so on until the child has readiness to enter the proper thematic play activities. Fantasy play activities (fantastic play) offer a lot of influence for children on various aspects of knowledge, attitudes and behaviour. Educators are greatly helped by fantasy play activities (fantastic play). Children become more understanding, give more impression to children, and children's imagination is honed.

\subsubsection{Practical Life Training Programs and Practices}

Practical life training programs and practices are among the leading programs and best practices recognized by stakeholders, especially parents and educators themselves. Practical life training programs and exercises through various forms of habituation and exercise activities for each child with the aim that children can take care of their own needs. These practical life training programs and activities illustrate the following: (1) Toilet training; (2) hand washing; (3) Take off and wear shoes; (4) Take off and wear clothes; (5) Folding clothes; (6) Tidy up the bag; (7) Eating; (8) Bathing.

\subsection{Discussion}

\subsubsection{Play Based Curriculum in Context Analysis}

Context analysis is an approach and process that is carried out in conducting self-evaluation of an institution. ECE Ceria Education Institution (TTKA), Faculty of Education at Universitas Negeri Jakarta program does not yet have an institution's self-evaluation document, as well as the institution's operational permit from the education office. This is part of the weakness of the education unit from the fact at the heart of educational institutions. Thus, self-evaluation cannot yet become a foundation or footing to make sure compliance with the needs of the model and curriculum approaches in the TTKA Ceria ECE unit, Faculty of Education at Universitas Negeri Jakarta program.

\subsubsection{Platform for Play Based Curriculum}

The foundation of curriculum development has been stated in the TTKA Ceria of Faculty of Education at Universitas Negeri Jakarta program curriculum document, but it has not been compiled in the form of a separate academic text. This is still possible if the curriculum development foundation is laid out in a separate section or special chapter in the curriculum document. The foundation in developing curriculum based on play at the TTKA Institute tends to use an emergent curriculum or curriculum approach by adapting the needs and stages of child development. The teacher does not understand this curriculum approach conceptually or practically because of the lack of socialization and is not involved in the preparation of the curriculum development foundation. In addition to the approach, the TTKA Ceria also adopted the DAP approach. This approach seeks to develop programs and early childhood play activities that are appropriate to the interests, needs and stages of early childhood development. This DAP approach is in line with the emergent curriculum approach which has the same conceptual and philosophical basis.

\subsubsection{Play Based Curriculum in KTSP TTKA Ceria}

The concept of play-based curriculum does not explicitly specify and write it down in the KTSP TTKA Ceria document. The concept of playing-based curriculum is more implicit 
explain the emergent curriculum approach and the DAP approach. The key concept using these two approaches is children's play programs and activities by analysing and adjusting children's interests, needs and stages of development. Contain the program for children's independence and fantasy play does not seem and is contained in the TTKA Ceria curriculum document. Educators have a relatively similar view that the advantages of the Institute are programs and exercises of independence in children. But the program is not listed in the vision and mission of the TTKA Ceria ECE Institution.

\subsubsection{Play-Based Curriculum Learning Tools}

The TTKA Ceria Faculty of Education at Universitas Negeri Jakarta program already has a learning device document in the form of developing themes, syllabi and daily learning implementation plans. In the document, the concept of play-based learning develop thematic activities and daily learning plan implementation documents, especially in the first column are play activities. The process of playing activities in two stages, namely playing the pre-theme and playing with the theme.

\subsubsection{Play Based Learning Process}

TTKA Ceria Institute presents play-based learning activities using the center model. The process of playing the center at the play center preparation activities, playing at the arts center, playing at the center of development and playing activities at the exploration center. In addition to core play activities at the center, play activities start when children come to the Institute and children play freely. Play activities are also seen in circle time by guessing, singing and telling stories.

In addition to play activities, learning uses habituation, especially habituation with the aim of building children's independence. Habituation activities start when the child comes to open shoes and bags and keep them in their place. Habitual activities also occur when children exercise to the toilet. Exercise to the toilet through taking off and wearing your own clothes, bathing and cleaning the body with own soap and shampoo.

\subsubsection{Management of Play Based Learning Classes}

Classroom management in general through a four center learning center model. Class management relatively does not change much from time to time except when changing themes. manage center classes, educators prepare types of play and tools by the theme.

\subsubsection{Results of Development Assessment}

The results of assessment of child development using observation and portfolio methods. Educators record and make descriptions of child development on indicators and aspects of development that arise and indicators with targets related to the theme. The results of describe child development are the basis for determining the level of achievement of child development. The results of child development achievements are used as material for child development reports for end of semester activities.

\subsubsection{Program Development in Play Based Curriculum}

Program development carry out the TTKA Ceria curriculum compiles and formulates the curriculum when work meetings take place ahead of the new school year. The results of the work meeting usually map and find the programs and activities in a year that support achieve educational goals in Ceria TTKA. 


\subsubsection{SOP of Play Based Curriculum}

TTKA Ceria only has a number of standard operating procedures (SOP) on the main activities. Some SOPs are SOPs for accepting new students and SOP for reporting child development.

\section{CONCLUSION}

\subsection{Conclusion}

Play-based curriculum implementation is the choice of the main model in implementing learning in early childhood. The choice of the concept of playing into the spirit in the curriculum becomes the main agreement of early childhood education experts. On that basis, early childhood education services in units and types of programs must accommodate and adapt the concept of play-based curriculum. Likewise, the implementation of education in the Day Care education laboratory of TTKA Ceria ECE, Faculty of Education, Jakarta State University needs and must use concepts and models of play-based curriculum, especially learning models with full day concepts (full day school).

Evaluative research at TTKA Ceria concludes that curriculum benchmarks have not been compiled and developed through measurable academic ideas and concepts and implemented appropriately. The use of the emergent curriculum approach and the DAP approach need good understanding and mastery of teacher competencies in various ways, especially in mastering the development and learning of children, curriculum and learning models as well as assessment of child development.

The implementation of the play-based curriculum concept has not been clear and explicit and explicit in the TTKA Ceria curriculum documents. As a result, the development of learning tools also does not adequately accommodate the concept of play-based curriculum, especially in the commitment to provide adequate play density and play time for each child. The play-based learning process is already clear when children begin to enter ECE TTKA Ceria through free play activities and especially when children play at centers.

\subsection{Suggestion}

Based on the conclusions of this research, this study conveys the following recommendations:

- The coordinator of the ECE Educator Program study program needs to conduct a thorough evaluation of the place, function, concept and implementation of ECE services in TTKA Ceria. The recommendation aims to clarify the status of the TTKA Ceria licensing as an educational laboratory as well as the concept and model reference.

- The implementing coordinator and technical implementer of the TTKA Ceria laboratory need to have a planned, scheduled and ongoing discussion with lecturers who have the competence and experience in managing educational institutions. This aims to make sure the concept and implementation of the curriculum uses a clear and measurable academic footing.

- Educators need to recognize and reflect on their academic experience and practice while attending lectures at ECE Educator Program, Faculty of Education at Universitas Negeri Jakarta program. In addition, educators need to update their understanding of concepts and trends in the development of ECE concepts and practices that are developing.

\section{REFERENCES}

Alford, B. L., Rollins, K. B., Padrón, Y. N., \& Waxman, H. C. (2016). Using Systematic 
Classroom Observation to Explore Student Engagement as a Function of Teachers' Developmentally Appropriate Instructional Practices (DAIP) in Ethnically Diverse Prekindergarten Through Second-Grade Classrooms. Early Childhood Education Journal, 44(6), 623-635. https://doi.org/10.1007/s10643-015-0748-8

Ali, E., Kaitlyn M, C., Hussain, A., \& Akhtar, Z. (2018). the Effects of Play-Based Learning on Early Childhood Education and Development. Journal of Evolution of Medical and Dental Sciences, 7(43), 4682-4685. https://doi.org/10.14260/jemds/2018/1044

Ashiabi, G. S. (2007). Play in the preschool classroom: Its socioemotional significance and the teacher's role in play. Early Childhood Education Journal, 35(2), 199-207. https://doi.org/10.1007/s10643-007-0165-8

Berk, L. E., \& Meyers, A. B. (2013). The role of make-believe play in the development of executive function. American Journal of Play, 6(1), 98-110.

Bodrova, E., Germeroth, C., \& Leong, D. J. (2013). Play and Self-Regulation: Lessons from Vygotsky. American Journal of Play, 6(1), 111-123. Retrieved from http://eric.ed.gov/?id=EJ1016167

Chien, N. C., Howes, C., Burchinal, M., Pianta, R. C., Ritchie, S., Bryant, D. M., ... Barbarin, O. A. (2010). Children's classroom engagement and school readiness gains in prekindergarten. Child Development, 81(5), 1534-1549. https://doi.org/10.1111/j.1467-8624.2010.01490.x

Cortázar, A. (2015). Long-term effects of public early childhood education on academic achievement in Chile. Early Childhood Research Quarterly, 32, 13-22. https://doi.org/10.1016/j.ecresq.2015.01.003

Danniels, E., \& Pyle, A. (2018). Defining Play-based Learning. In Encyclopedia on Early Childhood Development (Play-Based, pp. 1-5). OISE University of Toronto.

Ejuu, G., Apolot, J. M., \& Serpell, R. (2019). Early childhood education quality indicators: Exploring the landscape of an African community perspective. Global Studies of Childhood. https://oi.org/10.1177/2043610619832898

Faas, S., Wu, S.-C., \& Geiger, S. (2017). The Importance of Play in Early Childhood Education: A Critical Perspective on Current Policies and Practices in Germany and Hong Kong. Global Education Review, 4(2), 75-91.

Fisher, K. R., Hirsh-Pasek, K., Newcombe, N., \& Golinkoff, R. M. (2013). Taking shape: Supporting preschoolers' acquisition of geometric knowledge through guided play. Child Development, 84(6), 1872-1878. https://doi.org/10.1111/cdev.12091

Hennessey, P. (2016). Full - Day Kindergarten Play-Based Learning: Promoting a Common Understanding. Education and Early Childhood Development, (April), 1-76. Retrieved from gov.nl.ca/edu

Holt, N. L., Lee, H., Millar, C. A., \& Spence, J. C. (2015). 'Eyes on where children play': a retrospective study of active free play. Children's Geographies, 13(1), 73-88. https://doi.org/10.1080/14733285.2013.828449

Jay, J. A., \& Knaus, M. (2018). Embedding play-based learning into junior primary (Year 1 and 2) Curriculum in WA. Australian Journal of Teacher Education, 43(1), 112-126. https://doi.org/10.14221/ajte.2018v43n1.7

Kathy, E. (2016). Play-based versus Academic Preschools. Parent Cooperative Preschool International, 1-3.

Klenowski, V., \& Wyatt-Smith, C. (2012). The impact of high stakes testing: The Australian story. Assessment in Education: Principles, Policy and Practice, 19(1), 65-79. https://doi.org/10.1080/0969594X.2011.592972 
Martlew, J., Stephen, C., \& Ellis, J. (2011). Play in the primary school classroom? The experience of teachers supporting children's learning through a new pedagogy. Early Years, 31(1), 7183. https://doi.org/10.1080/09575146.2010.529425

Mcginn, A. (2017). Play-based early childhood classrooms and the effect on pre-kindergarten social and academic achievement (University of Northern Iowa). Retrieved from https://scholarworks.uni.edu/grp

Miller, E., \& Almon, J. (2009). Crisis in the Kindergarten. Why children need to to Play in School. In Alliance for childhood. Retrieved from www.allianceforchildhood.org.

Özerem, A., \& Kavaz, R. (2013). Montessori Approach in Pre-School Education and Its Effects. Tojned The Online Journal of New Horizons in Education, 3(3), 12-25.

Pendidikan, K., \& Kebudayaan, D. A. N. Menteri Pendidikan Dan Kebudayaan Republik Indonesia Nomor 137 Tahun 2013 Tentang Standar Nasional Pendidikan Anak Usia Dini., (2015).

Peng, Q. (2017). Study on Three Positions Framing Kindergarten Play-Based Curriculum in China: Through Analyses of the Attitudes of Teachers to Early Linguistic Education. Studies in English Language Teaching, 5(3), 543. https://doi.org/10.22158/selt.v5n3p543

Pyle, A., \& Bigelow, A. (2015). Play in Kindergarten: An Interview and Observational Study in Three Canadian Classrooms. Early Childhood Education Journal, 43(5), 385-393. https://doi.org/10.1007/s10643-014-0666-1

Pyle, A., \& Danniels, E. (2017). A Continuum of Play-Based Learning: The Role of the Teacher in Play-Based Pedagogy and the Fear of Hijacking Play. Early Education and Development, 28(3), 274-289. https://doi.org/10.1080/10409289.2016.1220771

Reid, A. (2009). Is this a revolution?: A critical analysis of the Rudd government's national education agenda. Curriculum Perspectives, 29(3), 1-13.

Ridgway, A., \& Quinones, G. (2012). How do early childhood students conceptualize play-based curriculum? Australian Journal of Teacher Education, 37(12), 46-56. https://doi.org/10.14221/ajte.2012v37n12.8

Rogers, S., \& Evans, J. (2007). Rethinking role play in the Reception class. Educational Research, 49(2), 153-167. https://doi.org/10.1080/00131880701369677

Samuelsson, I. P., \& Johansson, E. (2006). Play and learning-inseparable dimensions in preschool practice. Early Child Development and Care, 176(1), 47-65. https://doi.org/10.1080/0300443042000302654

Saracho, O. N. (2010). Children's play in the visual arts and Literature. Early Child Development and Care.

Saracho, O. N. (2013). An integrated play-based curriculum for young children. In An Integrated Play-Based Curriculum for Young Children. https://doi.org/10.4324/9780203833278

Stufflebeam, D. L. (2003). The CIPP model for evaluation. In Oregon Program Evaluators Network (pp. 31-62). https://doi.org/doi:10.1007/978-94-010-0309-4_4

Sturgess, J. (2003). A model describing play as a child-chosen activity - Is this still valid in contemporary Australia? Australian Occupational Therapy Journal, 50(2), 104-108. https://doi.org/10.1046/j.1440-1630.2003.00362.x

Taylor, M. E., \& Boyer, W. (2020). Play-Based Learning: Evidence-Based Research to Improve Children's Learning Experiences in the Kindergarten Classroom. Early Childhood Education Journal, 48(2), 127-133. https://doi.org/10.1007/s10643-019-00989-7

Thompson, G. (2013). NAPLAN, myschool and accountability: Teacher perceptions of the effects 
of testing. International Education Journal, 12(2), 62-84.

van Oers, B. (2012). Developmental education for young children: Concept, practice and implementation. Developmental Education for Young Children: Concept, Practice and Implementation, 1-302. https://doi.org/10.1007/978-94-007-4617-6

van Oers, B. (2015). Implementing a play-based curriculum: Fostering teacher agency in primary school. Learning, Culture and Social Interaction, 4, 19-27. https://doi.org/10.1016/j.lcsi.2014.07.003

van Oers, B., \& Duijkers, D. (2013). Teaching in a play-based curriculum: Theory, practice and evidence of developmental education for young children. Journal of Curriculum Studies, 45(4), 511-534. https://doi.org/10.1080/00220272.2011.637182

Wallerstedt, C., \& Pramling, N. (2012). Learning to play in a goal-directed practice. Early Years, 32(1), 5-15. https://doi.org/10.1080/09575146.2011.593028

Weisberg, D. S., Zosh, J. M., Hirsh-Pasek, K., \& Golinkoff, R. M. (2013). Talking it up: Play, langauge, and the role of adult support. American Journal of Play, 6(1), 39-54. Retrieved from http://www.journalofplay.org/issues/6/1/article/3-talking-it-play-languagedevelopment-and-role-adult-support

Wong, S. M., Wang, Z., \& Cheng, D. (2011). A play-based curriculum: Hong Kong children's perception of play and non-play. International Journal of Learning, 17(10), 165-180. https://doi.org/10.18848/1447-9494/cgp/v17i10/47298 